\title{
Interventions to prevent elder abuse in the community: a mixed-methods systematic review
}

\author{
Intervenções para prevenir o abuso de idosos na comunidade: \\ uma revisão sistemática de métodos mistos \\ Intervenciones para prevenir el abuso de personas mayores en la \\ comunidad: una revisión sistemática de métodos mixtos
}

How to cite this article:

Sousa RCR, Araújo-Monteiro GKN, Souto RQ, Santos RC, Leal CQAM, Nascimento NM. Interventions to prevent elder abuse in the community: a mixedmethods systematic review. Rev Esc Enferm USP. 2021;55:e3677. doi: https://doi.org/10.1590/S1980-220X2019033203677

Rute Costa Régis de Sousa ${ }^{1}$

Gleicy Karine Nascimento de Araújo-Monteiro

(iD) Rafaella Queiroga Souto ${ }^{2}$

Renata Clemente dos Santos ${ }^{2}$

(iD) Cláudia Quézia Amado Monteiro Leal $^{2}$

Neyce de Matos Nascimento ${ }^{2}$

${ }^{1}$ Universidade Federal de

Pernambuco, Departamento de

Enfermagem, Recife, PE, Brazil.

${ }^{2}$ Universidade Federal da Paraíba, Departamento de Enfermagem, João Pessoa, PB, Brazil.

\begin{abstract}
Objective: To identify the interventions proposed in the literature aimed at preventing elder abuse among community-residing elders. Method: This was a mixed-methods systematic review that followed the Preferred Reporting Items for Systematic Review and Meta-analysis Protocols checklist. The protocol of this systematic review was registered in the International Prospective Register of Systematic Reviews. We included studies published between January 2004 and December 2019 in the databases: LILACS, IBECS, CUMED, CINAHL, MEDLINE and SciELO. The methodological quality of each study included was performed using the Mixed Methods Appraisal Tool. Results: Seven studies formed the final sample. Two groups emerged after the analyses: the primary level intervention group, which used health education and coexisting elder abuse groups; and the secondary intervention level, focused mostly on the mental health care of victims of elder abuse. Conclusion: There is still a shortage of intervention studies to prevent elder abuse. All the studies selected had a positive outcome, and all interventions can be implemented in nursing care practice.
\end{abstract}

DESCRIPTORS

Elder Abuse; Violence; Geriatric Nursing, Systematic Review.
Corresponding author:

Rafaella Queiroga Souto

Universidade Federal da Paraíba

Cidade Universitária, s/n - Castelo Branco III,

CEP 58051-085 - João Pessoa, PB, Brazil

rafaellaqueiroga7@gmail.com
Received: 10/23/2019

Approved: 08/03/2020 


\section{INTRODUCTION}

The World Health Organization (WHO) defines elder abuse as: "actions or omissions committed once or many times that impair the physical and emotional integrity of elder persons and prevent the performance of their social role"(1). The Brazilian Elderly Statute defines elder abuse in a very similar way to the WHO definition, "as any action or omission practiced in a public or private place that causes death, damage or physical or psychological suffering to the elderly"(2).

Risk factors for elder abuse in the community can be classified as relating to the following four categories: the elderly, the perpetrator, the relationship and the environment ${ }^{(3)}$. Elderly-related factors include cognitive impairment, behavioral problems, psychological problems, dependence, poor physical health or frailty, low income or wealth, past trauma or abuse and ethnicity. Perpetrator-related risk factors include caregiver overload, mental illness, being a victim of domestic violence, and substance abuse. Relationship-related risk factors are family disharmony, and weak family affective bonds. Environmental risk factors are social isolation and a low level of social support ${ }^{(4-5)}$. The relational and environmental factors are the most strongly associated with elder abuse ${ }^{(3)}$.

Elder abuse has been associated with a higher risk of premature death, a higher use of health services (especially emergency services and hospital admissions) ${ }^{(6)}$, a higher use of long-term care facilities, disability, chronic pain, bankruptcy, psychosocial suffering ${ }^{(7-9)}$, and poor physical health ${ }^{(10)}$, and it has thus become a public health problem.

An intervention based on a public health model aimed at preventing elder abuse should operate at the levels of primary, secondary and tertiary interventions: primary interventions target the whole population victim of elder abuse to prevent elder abuse; secondary interventions focus on early identifying and stopping the occurrence of elder abuse; tertiary interventions target elderly people who are victims of abuse and focus on preventing the recurrence of abuse ${ }^{(11-12)}$.

Despite the increased visibility of this subject in recent decades, scientific production remains deficient, particularly with respect to studies on interventions to prevent elder abuse $^{(11)}$. In addition to the limited data on preventionoriented interventions ${ }^{(13)}$, few interventions are based on scientifically grounded hypotheses and have had their efficacy and effectiveness measured ${ }^{(14)}$. A justification for this scenario can be the few solidified theoretical models that fully explain how these relationships of elder abuse develop, in comparison to studies explaining other forms of violence such as child abuse and violence against women ${ }^{(15)}$.

Despite the availability of quite a few systematic reviews of interventions to prevent elder abuse, there are no mixedmethods systematic reviews on this subject ${ }^{(11,16-19)}$, although a multifactorial and complex subject such as this demands the combined strengths of quantitative and qualitative methods.

Given this scenario, it was necessary to review the scientific literature to answer the following research question: Which strategies are adopted in the interventions to prevent elder abuse in the community?
Accordingly, the aim of this study is to identify the interventions proposed in the literature directed to the prevention of elder abuse in the community.

\section{METHOD}

\section{TYPE OF STUDY}

This review followed the Preferred Reporting Items for the Systematic Review and Meta-analysis Protocols (PRISMA-P) checklist. The PRISMA-P checklist contains 17 basic items that should be described in a systematic review protocol. The use of a systematic review protocol is important because it ensures rigor and reliability, as it allows for careful and anticipated planning, comparison and replication of the review, and prevents arbitrary and random decision making with respect to inclusion and exclusion criteria ${ }^{(20)}$. The protocol of this systematic review was registered in the International Prospective Register of Systematic Reviews (PROSPERO) under protocol number CRD42018084565.

This was a mixed-methods systematic review characterized by the synthesis of data or results from studies with different designs, that is, quantitative, qualitative and mixed methods ${ }^{(21)}$. Because the study question we plan to answer lies within the purview of public health, the mixed-methods systematic review is the most appropriate approach, since public health interventions are complex and cannot be limited to exclusively qualitative or quantitative approaches ${ }^{(22)}$.

\section{SeleCtION CRITERIA}

Criteria for including articles in this review were: full text available in English, Portuguese or Spanish; describing an intervention to prevent or control elder abuse; focused on the community setting; and publication between January 2004 and December 2019. This time period was chosen for this review because 2002 is the year that marks the Second World Assembly on Ageing (WAA) held in Madri, Spain, where world governments gathered to set out the blueprint for an international response to the opportunities and challenges of population ageing in the twenty-first century ${ }^{(23)}$.

The following studies were excluded: observational studies; those that did not define the victims of abuse as being at least 60 years-old; studies of an elder abuse population living in long-term care facilities; medical guides, reviews, comments, technical and scientific reports, ministerial documents, government information, dissertations, theses or monographs; and studies that did not demonstrate ethical conduct.

\section{Search strategy}

The secondary databases accessed were Latin American and Caribbean Literature in Health Sciences (LILACS), the Spanish Bibliographical Index of Health Sciences (IBECS), CUMED, the Cumulative Index of Nursing and Allied Health Literature (CINAHL), PubMed and Scientific Electronic Library Online (SciELO). This search phase was performed in December 2019 by two researchers, who worked independently.

The PICo strategy ${ }^{(24)}$ was used to define the research question and was structured as follows: Population of interest 
- Elder people living in the community; Intervention Intervention aimed at prevention/control of violence; Context - Preventing abuse of elders living in the community. Item $\mathrm{C}$ of the PICo strategy was not used, since this study was not restricted to clinical trials with a group comparison. Thus, we considered the context ( $\mathrm{Co}$ ) of the study. Based on each item of the PICo strategy, both Descriptors in Health Sciences (DeCS) and keywords were found, enabling us to compose the search strategy. Once chosen, the descriptors and keywords were then combined by using the Boolean operators OR and AND for application in the databases, as shown in Chart 1.

Chart 1 - Search strategies used in databases.

\begin{tabular}{|c|c|}
\hline $\begin{array}{l}\text { Database } \\
\text { Online Library }\end{array}$ & Search strategies \\
\hline $\begin{array}{l}\text { LILACS, IBECS } \\
\text { and CUMED (via } \\
\text { Virtual Library } \\
\text { of Health - VHL) }\end{array}$ & $\begin{array}{c}\text { (Idoso OR "Pessoa Idosa" OR "Pessoa De Idade" OR "População Idosa" OR "Terceira Idade") AND ("Educação em } \\
\text { Saúde" OR "Ensaio Clínico" OR “Estudo de Intervenção" OR Intervenção OR Educação OR “Intervenção Educativa") } \\
\text { AND ("Maus-tratos ao Idoso" OR Violência OR "Violência Doméstica" OR "Violência na Família" OR "Violência } \\
\text { Sexual" OR “Abuso Físico" OR Estupro OR Abuso OR Maus-tratos). Filters: language (English, Portuguese and } \\
\text { Spanish); publication year (2004 to 2019) and type of document (article). }\end{array}$ \\
\hline PubMed & $\begin{array}{l}\text { (Aged OR Elderly OR "Older People" OR "Ageing People" OR Ageing OR "Older Adults" OR Age) AND ("Health } \\
\text { Education" OR "Clinical Trial" OR "Intervention Studies" OR Interventions) AND ("Sexual Violence" OR "Domestic } \\
\text { Violence" OR "Aged Abuse" OR “Elder Neglect" OR "Elder Abuse" OR "Violence" OR "Family Violence" OR } \\
\text { "Physical Abuse" OR Rape OR Mistreatment OR "Elderly Victimization" OR "Crime Prevention" OR "Elder } \\
\text { Mistreatment" OR "Financial Violence"). Filters: language (English, Portuguese and Spanish); year of publication } \\
\text { (2004 to 2019) and type of document (article). }\end{array}$ \\
\hline $\begin{array}{l}\text { SciELO } \\
\text { (via scielo.br) }\end{array}$ & $\begin{array}{l}\text { (Aged OR Elderly OR "Older People" OR "Ageing People" OR Ageing OR "Older Adults" OR Age) AND ("Health } \\
\text { Education" OR "Clinical Trial" OR "Intervention Studies" OR Interventions) AND ("Sexual Violence" OR "Domestic } \\
\text { Violence" OR "Aged Abuse" OR "Elder Neglect" OR "Elder Abuse" OR "Violence" OR "Family Violence" OR } \\
\text { "Physical Abuse" OR Rape OR Mistreatment OR “Elderly Victimization" OR "Crime Prevention" OR "Elder } \\
\text { Mistreatment" OR "Financial Violence"). Filters: language (English, Portuguese and Spanish); year of publication } \\
\text { (2004 to 2019) and type of document (article). }\end{array}$ \\
\hline $\begin{array}{l}\text { CINAHL (via } \\
\text { Ebsco Host) }\end{array}$ & $\begin{array}{l}\text { (Aged OR Elderly OR "Older People" OR "Ageing People" OR Ageing OR "Older Adults" OR Age) AND ("Health } \\
\text { Education" OR "Clinical Trial" OR "Intervention Studies" OR Interventions) AND ("Sexual Violence" OR "Domestic } \\
\text { Violence" OR "Aged Abuse" OR “Elder Neglect" OR "Elder Abuse" OR "Violence" OR "Family Violence" OR } \\
\text { "Physical Abuse" OR Rape OR Mistreatment OR “Elderly Victimization" OR "Crime Prevention" OR "Elder } \\
\text { Mistreatment" OR "Financial Violence" ). Filters: language (English, Portuguese and Spanish); year of publication } \\
\text { (2004 to 2019) and type of document (article). }\end{array}$ \\
\hline
\end{tabular}

The literature search results were added and managed using a free reference management software (MendeleyDesktop version 1.17.7; London-England). The use of this type of tool reduces the likelihood of errors in the cataloging of studies found.

The selection of studies was performed independently by two researchers. This selection was performed in three steps: (1) an initial screening that involved reading only the title, (2) a second screening that involved reading the abstract, and (3) a third screening that involved reading the full text. Disagreements were resolved by a third researcher.

\section{DATA ANALYSIS AND TREATMENT}

This review used a convergent synthesis approach to analyze the mixed-method studies found, specifically the parallel-results convergent synthesis design that consists of independent syntheses of qualitative and quantitative evidence and an interpretation of the results in the discussion ${ }^{(25)}$. Our study quality analysis was performed using the Mixed Methods Appraisal Tool (MMAT), which is a checklist developed to provide a quality assessment tool for quantitative, qualitative and mixed-method studies included in mixed-methods systematic reviews ${ }^{(21)}$. The MMAT criteria were developed based on an analysis of the quality assessment items of the reviewed studies of 17 mixed-methods systematic reviews in the health field. The MMAT is focused on the public health context, particularly for issues related to complex interventions, and therefore, its use in the context of elder abuse is appropriate ${ }^{(26)}$.

The MMAT is comprised of four sections, one for each study design: qualitative studies, randomized controlled trials, nonrandomized studies, and mixed methods. Each section has a different number of items that can be answered with either yes, no or I can't tell; the authors can give a score to each answer in order to have a final score of all studies assessed. In this review, the MMAT was used to analyze the methodological quality of the selected studies, but no score was attributed to the studies, and neither was MMAT an exclusion criterion for this review ${ }^{(21)}$.

Data were extracted to preserve the context of the findings, as described in a study that addressed techniques to extract findings in mixed-method synthesis studies ${ }^{(27)}$. This data extraction process was performed using two instruments developed by the researcher. The first instrument contained metadata of the study: journal of publication, authors, institution of the main author, year of publication and country of study. The second instrument was the type of study, purpose of the study, number of participants, location, type of violence, intervention, level of prevention targeted by the study, evaluation of results, and limitations of the study. 


\section{ETHICAL ASPECTS}

Because of the nature of this study, approval from a Research Ethics Committee was unnecessary.

\section{RESULTS}

Based on the search strategy and the inclusion and exclusion criteria presented in the methodology, seven studies constituted the final sample ${ }^{(28-34)}$. Figure 1 presents the selection process for these manuscripts.
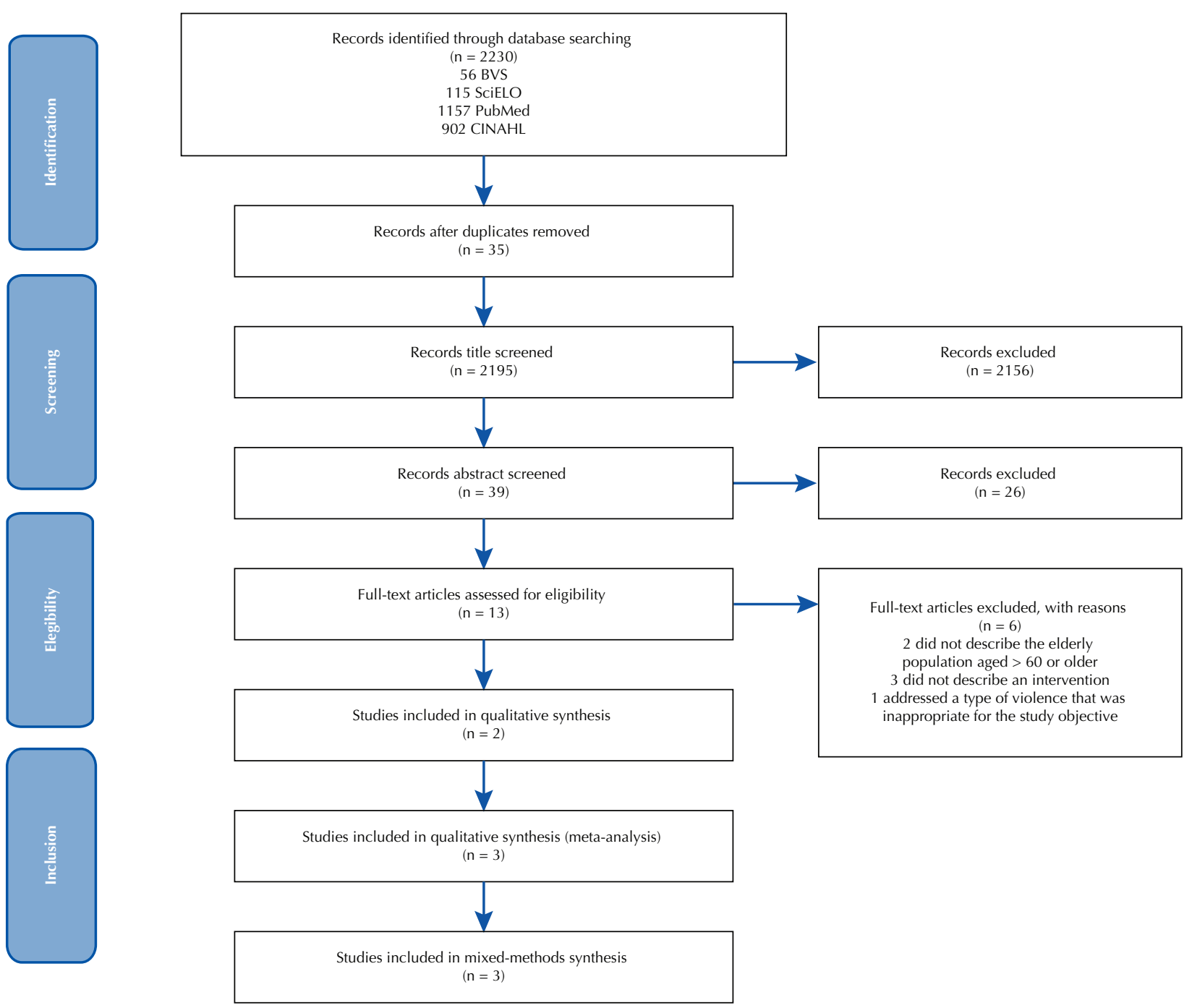

Figure 1 - PRISMA flowchart of the selection process of studies according to PRISMA.

The earliest study selected for this review ${ }^{(28)}$ was published in 2007, and the most recent in $2018^{(34)}$. The year with the highest number of publications was 2011, with two selected studies $^{(30-31)}$. There was a predominance of studies from countries in the North ${ }^{(28-30)}$ and Central America ${ }^{(31-33)}$, with only Iran $^{(34)}$ providing a study from outside these areas.

Four of the institutions of origin of the main author were universities $^{(28,31,33-34)}$, two were health services agencies ${ }^{(29,32)}$ and one was a domestic violence victim service agency ${ }^{(30)}$. Two studies were of mixed-methods ${ }^{(32-33)}$, two were qualitative ${ }^{(28,30)}$ and three were quantitative ${ }^{(29,31,34)}$. The number of participants in each intervention ranged from two ${ }^{(30)}$ to $69^{(29)}$ victims of elder abuse, but this information is absent in one of the studies ${ }^{(32)}$.
In two of the selected studies, the target population of the intervention were both the elder abuse victims and their relatives $^{(28,33)}$, while another study was focused only on elder abuse female victims of violence ${ }^{(30)}$. The most often addressed type of elder abuse among the selected studies was a broad, unspecified form of violence ${ }^{(28-29,32-34)}$.

Chart 2 details the interventions described in each study. Only two levels of prevention targeted in these interventions emerged in the articles: primary and secondary prevention. Interventions focused on the elder abuse who had not yet been identified as victims of violence ${ }^{(31-34)}$, and on the elder abuse who were already victims of violence ${ }^{(28-30)}$. 
Chart 2 - Aims, interventions and outcomes of selected articles.

\begin{tabular}{|c|c|c|c|}
\hline $\begin{array}{l}\text { Authors } \\
\text { (year) }\end{array}$ & Aims & Interventions & Outcomes \\
\hline $\begin{array}{l}\text { Holkup et al. } \\
(2007)^{(28)}\end{array}$ & $\begin{array}{l}\text { Describes an elderly, family- } \\
\text { centered and community-based } \\
\text { intervention: Family Care } \\
\text { Conference (FCC). }\end{array}$ & $\begin{array}{l}\text { The FCC has six steps: } \\
\text { referral, screening, family } \\
\text { involvement, logistical } \\
\text { preparation, family reunion } \\
\text { and follow-up. }\end{array}$ & $\begin{array}{l}\text { During the follow-up phase, family meetings are held to } \\
\text { evaluate the results achieved by the family, in order to identify } \\
\text { any necessary changes to the plan and provide positive } \\
\text { encouragement. The number of meetings will depend on how } \\
\text { difficult the family found it to implement the proposed plan; of } \\
\text { the } 10 \text { families that participated in the project, five managed to } \\
\text { solve their problems in only one meeting, four had two family } \\
\text { meetings, and one had three family meetings. }\end{array}$ \\
\hline $\begin{array}{l}\text { Sirey et al. } \\
(2015)^{(29)}\end{array}$ & $\begin{array}{l}\text { Examine the feasibility of } \\
\text { implementing routine screening } \\
\text { for depression and anxiety in a } \\
\text { system of elder abuse services; } \\
\text { test the acceptability of a mental } \\
\text { health intervention called } \\
\text { Providing Options to Elderly } \\
\text { Clients Together (PROTECT) } \\
\text { to improve depression and the } \\
\text { outcomes of elder abuse cases; } \\
\text { identify the most acceptable } \\
\text { format for providing mental } \\
\text { health services in the practice of } \\
\text { elder abuse. }\end{array}$ & $\begin{array}{l}\text { The PROTECT intervention } \\
\text { combines problem-solving } \\
\text { psychotherapy with anxiety } \\
\text { management techniques. } \\
\text { The PROTECT resolution } \\
\text { therapy is applied in eight } \\
\text { sessions, with (at least) the } \\
\text { first session held in person. } \\
\text { Each subsequent session } \\
\text { is conducted using either } \\
\text { face-to-face meeting or } \\
\text { face-to-face problem-solving } \\
\text { worksheets. }\end{array}$ & $\begin{array}{l}\text { The degree of completion of activities, client satisfaction, } \\
\text { response to elder abuse interventions and perceived } \\
\text { improvement are documented in session progress notes by the } \\
\text { PROTECT therapist. The article did not contain any results on } \\
\text { the effectiveness of the intervention strategy used. }\end{array}$ \\
\hline $\begin{array}{l}\text { Tetterton, } \\
\text { Farnsworth } \\
(2011)^{(30)}\end{array}$ & $\begin{array}{l}\text { Increase the understanding } \\
\text { of professionals about } \\
\text { Interpersonal Violence (IPV) } \\
\text { in elder abuse women; } \\
\text { discuss barriers faced by } \\
\text { this population; describe } \\
\text { interventions used when } \\
\text { dealing with IPV cases in elder } \\
\text { abuse women. }\end{array}$ & $\begin{array}{l}\text { The authors conducted two } \\
\text { case studies with elder abuse } \\
\text { female victims of IPV and } \\
\text { identified three essential } \\
\text { positions that should be } \\
\text { adopted by professionals } \\
\text { when performing any } \\
\text { intervention with elder } \\
\text { abuse female victims of IPV. } \\
\text { These positions were: user } \\
\text { embracement and captivation } \\
\text { of clients; encouraging and } \\
\text { supporting the narration of } \\
\text { their stories; and offering } \\
\text { assistance in the process of } \\
\text { empowerment. }\end{array}$ & $\begin{array}{l}\text { The case study and the research notes provided data that } \\
\text { supported the conceptualization of effective interventions } \\
\text { for elder abuse women who had experienced IPV. Both } \\
\text { women began to regain control by identifying and resolving } \\
\text { vulnerabilities that others had used against them for decades. } \\
\text { The researchers identified this as "empowerment from within" } \\
\text { to recognize the long and hard work that older women } \\
\text { themselves must carry out to deal with IPV. }\end{array}$ \\
\hline $\begin{array}{l}\text { Vinent et al. } \\
(2011)^{(31)}\end{array}$ & $\begin{array}{l}\text { To carry out an educational } \\
\text { intervention to modify } \\
\text { knowledge on elder abuse. }\end{array}$ & $\begin{array}{l}\text { The program of activities } \\
\text { was carried out in eight work } \\
\text { sessions with themes related to } \\
\text { different types of violence and } \\
\text { their manifestations, causes } \\
\text { and consequences. Two-hour } \\
\text { sessions were held twice a } \\
\text { week. At the end of each } \\
\text { session, there were reflections } \\
\text { on what had been covered. }\end{array}$ & $\begin{array}{l}\text { After the educational intervention, the questionnaire was } \\
\text { again evaluated with the same initial characteristics, and the } \\
\text { knowledge modifications that occurred before and after the } \\
\text { intervention were evaluated. At the end of the intervention, all } \\
\text { the elder abuse people with inadequate knowledge showed a } \\
100 \% \text { increase in knowledge levels, with a significance level } \\
\text { of } p<0.05 \text {. }\end{array}$ \\
\hline $\begin{array}{l}\text { Fernández et } \\
\text { al. }(2012)^{(32)}\end{array}$ & $\begin{array}{l}\text { Apply an educational } \\
\text { intervention program that } \\
\text { promotes assertive behavior in } \\
\text { the elder abuse. }\end{array}$ & $\begin{array}{l}\text { The study used an Educational } \\
\text { Intervention Program } \\
\text { prepared by the group of } \\
\text { authors and advisors of this } \\
\text { research and validated by } \\
\text { expert criteria through the } \\
\text { methodology of preference, } \\
\text { with a total of } 10 \text { experts and } \\
\text { a } 10 \% \text { rate of error. }\end{array}$ & $\begin{array}{l}\text { The following methods were used at the beginning and end } \\
\text { of the program for diagnosis and evaluation: observation, } \\
\text { experience, focus group, interview, and triangulation of } \\
\text { techniques (interview and focus group) to obtain the results. } \\
\text { Five themes were addressed before and after the intervention: } \\
\text { attitude toward old age, daily activities, respect for the elderly, } \\
\text { attitude to sexuality in the elderly, and assertive attitude in } \\
\text { the elderly. All these aspects changed positively after the } \\
\text { intervention, but only the assertive attitude component of the } \\
\text { elder abuse resulted in a statistically significant change, } \mathrm{p} \\
<0.05 \text {. }\end{array}$ \\
\hline $\begin{array}{l}\text { Hernández et } \\
\text { al. }(2014)^{(33)}\end{array}$ & $\begin{array}{l}\text { Describe an educational } \\
\text { intervention to prevent } \\
\text { and control elder abuse; } \\
\text { characterize the victims } \\
\text { of violence according to } \\
\text { sociodemographic and } \\
\text { sociocultural variables; } \\
\text { determine the frequency of } \\
\text { elder abuse. }\end{array}$ & $\begin{array}{l}\text { An educational intervention } \\
\text { was conceived based on } \\
\text { specific teachings intended for } \\
\text { the family and the elder abuse } \\
\text { victim to prevent elder abuse, } \\
\text { based on instructions for } \\
\text { healthy lifestyles that promote } \\
\text { appropriate interpersonal } \\
\text { exchanges between different } \\
\text { generations. Manifestations } \\
\text { that can be identified as abuse } \\
\text { were also discussed. }\end{array}$ & $\begin{array}{c}\text { How the results were evaluated and whether there were } \\
\text { positive results as an outcome of the intervention were not } \\
\text { described. }\end{array}$ \\
\hline
\end{tabular}




\begin{tabular}{|c|c|c|c|}
\hline $\begin{array}{l}\text { Authors } \\
\text { (year) }\end{array}$ & Aims & Interventions & Outcomes \\
\hline $\begin{array}{l}\text { Etbsari et al., } \\
(2018)^{(34)}\end{array}$ & $\begin{array}{c}\text { Design and implement an } \\
\text { empowering educational } \\
\text { intervention to prevent elder } \\
\text { abuse. }\end{array}$ & $\begin{array}{l}\text { The content of the educational } \\
\text { interventions was based on } \\
\text { the dimensions of health } \\
\text { promoting behavior and } \\
\text { included physical activity, } \\
\text { recreation and entertainment, } \\
\text { sleep, nutrition, interpersonal } \\
\text { relations and social support, } \\
\text { responsibility for health, } \\
\text { mental health, and older } \\
\text { adult stress management. } \\
\text { Educational technology } \\
\text { methods, such as lectures, } \\
\text { questions and answers, } \\
\text { and problem-solving were } \\
\text { used. The intervention was } \\
\text { carried out in twenty } 45-\text { to } \\
60 \text {-minute training sessions } \\
\text { over } 6 \text { months. }\end{array}$ & $\begin{array}{l}\text { Knowledge of elder abuse, high self-efficacy, high social } \\
\text { support and high health promoting lifestyle was significantly } \\
\text { greater in the intervention group; the frequency of elder abuse } \\
\text { risk was also significantly lower in the intervention group after } \\
\text { the intervention. The intervention had the highest impact on } \\
\text { increasing social support and promoting healthy behaviors. }\end{array}$ \\
\hline
\end{tabular}

Three out of the four interventions that focused on primary prevention were of Cuban origin and used educational approaches aimed at modifying the concepts about what was or was not considered elder abuse ${ }^{(31)}$, teaching assertive behavior to the elder person ${ }^{(32)}$, and promoting adequate communication practices between the elder person and the family ${ }^{(33)}$ in order to strengthen family relations and prevent conflicts.

The other intervention was conducted in Iran, based on primary prevention and aimed to design and implement an elder abuse empowerment program for elder people who visited health centers in Tehran. The intervention content was similar to those developed in Cuba, although with a better methodological approach since it was a clinical trial ${ }^{(34)}$.

The studies of American origin that focused on secondary prevention were more heterogeneous regarding the type of intervention used. One such study, whose population were elderly women victims of interpersonal violence, described the most effective approaches used by the researchers when working with these victims in a counseling service ${ }^{(30)}$.

The selected study that focused on secondary prevention was published in 2015 and reported an intervention used with elder people who sought care at a referral service for elder abuse in New York ${ }^{(29)}$. This intervention was offered to victims with positive screening for depressive symptoms and anxiety. The intervention was based on the problem-solving theory and directly and indirectly influenced the outcome of violence cases because it taught problem-solving skills related to the violence that had occurred and addressed problems that both influenced the occurrence of violence and were the result of violence, such as depression and anxiety.

The oldest study selected that also addressed secondary prevention and was published in 2007 described a project called the Family Care Conference (FCC), which was developed on a tribal reservation, based on the elder person, the family and the community and promoted family reunions for families that were reported, referred by another service, or sought the project because they were facing difficulty with an elder family member ${ }^{(28)}$. This project was inspired by another project developed in New Zealand among the Maori ethnic group, and its principles involve restorative justice rather than the punitive justice prevalent in Western cultures.

\section{DISCUSSION}

During the analysis of the selected studies, two groups emerged: studies focused on primary prevention and studies focused on secondary prevention. This finding corroborates those reported in another study that investigated interventions against violence directed at elder people living in the community ${ }^{(35)}$. The primary prevention group was homogeneous: all four studies ${ }^{(31-34)}$ used educational strategies and developed their interventions in groups of elder people, two developed their interventions in existing groups of elder people, and the third and fourth developed their interventions in a group of elder people specifically created for the development of the intervention.

The organization of cohabitation groups for elder people is therapeutic in its own right, since social isolation is a risk factor ${ }^{(36)}$ that influences depression ${ }^{(37)}$. Greater social participation helps to form protective support networks, which can improve the symptomatology of depression. In addition to generating a sense of control and power in decision making, these support networks can help people cope with stressors, thus promoting supportive and caring relationships ${ }^{(38)}$.

Although three studies ${ }^{(31,33-34)}$ carried out educational interventions that clarified what is considered violence to elder people and their families, modified and elucidated concepts and typologies, and two of them ${ }^{(31,34)}$ showed results with statistical significance, with all participants in the intervention modifying the concepts concerning the understanding of violence, there is still no evidence that a better awareness of the concept of abuse has an effect on experiences of violence. 
Although no studies have demonstrated the relationship between the level of knowledge of violence and the probability of victimization, interventions such as those reported in these two selected studies are important because they improve elder people's knowledge of the subject and may influence the search for help in a situation of violence ${ }^{(39)}$.

A 2013 study investigated the elderly's understanding of violence and noted that psychological and physical violence were more easily perceived by the elder person than neglect and financial violence ${ }^{(38)}$.

One ${ }^{(30)}$ of the three studies in the secondary intervention group was based on two case studies of elder victims of intimate violence who sought counseling. It described the essential approaches in the care of these elder women, as well as approaches that should be essential in professional assistance to victims. The identified conduct was embracement and captivation of the client by encouraging and supporting the sharing of their stories and assisting in the empowerment process.

Empowerment can be defined as a significant change in experiences of power lived by individuals in their interactions in society. It is constructed through an interactive process in which individuals devoid of power establish a significant goal for themselves, aimed at increasing their power, and act and work toward achieving their goal through their internal and external resources, observing and reflecting on the impact of their actions ${ }^{(40)}$.

Regardless of its nature, violence is marked by the inability of the victims to prevent or stop abuse despite their efforts, generating a sense of powerlessness because the situation is not under their control ${ }^{(41)}$. Several studies report a relationship between the feeling of impotence and depression and depressive symptoms $s^{(3,8,36,40)}$.

Depression is an indicator of one's mental health state and can be characterized as either a risk factor or a consequence of elder abuse, therefore, it is key in the prevention and intervention actions against this violence ${ }^{(8)}$. In the context of domestic violence, empowerment is seen as one of the main targets to be achieved ${ }^{(42)}$. An increase in the sense of empowerment of victims of domestic violence is related to decreased depressive symptoms, decreased post-traumatic stress, greater chances of reporting new cases of abuse, and better long-term results in general ${ }^{(40-42)}$.

The interventions proposed in the above mentioned study ${ }^{(30)}$ occurred in the context of counseling elder female victims of intimate violence, using support and encouragement to narrate their stories along with the empowerment process as tools that can be used by any professional when providing care to elder victims of violence.

The second study ${ }^{(31)}$ in the secondary interventions group was focused on mental health as a risk factor and consisted of applying an educational intervention program that promoted assertive behavior in the elder person. Assertiveness can be defined as interpersonal behavior in which individual boundaries are established, and needs are expressed clearly and directly ${ }^{(43)}$. An assertive person demonstrates the ability to defend his or her own or another's rights in a calm and positive way without alienating the rights and feelings of others ${ }^{(44)}$. A similar approach was found in the clinical trial carried out in Tehran, which also focused on the elder people's assertiveness, but had a broader aim and also focused on promoting a healthy lifestyle, self-knowledge, and social support ${ }^{(34)}$.

Lack of assertiveness can manifest itself in two diametrically opposed ways: excessive kindness, that is, submission; or excessive hostility, that is, aggressiveness. This lack of assertiveness has been associated with several clinical problems, including anxiety, depression, severe mental illness, low self-esteem, and relationship satisfaction ${ }^{(45)}$. As previously shown, depression and the mental health status of the elder person are both the cause and the consequence of the violence suffered by the elder person ${ }^{(8)}$, therefore, interventions that target improvement of the mental wellbeing of the elder person qualify as both primary and secondary prevention of elder abuse.

Training that promotes assertiveness has been used successfully in a variety of contexts involving abuse; with students in the context of bullying ${ }^{(43,46-48)}$, with nurses in the context of conflicts between health professionals ${ }^{(4,49)}$, and in the context of domestic violence ${ }^{(33,50)}$.

The last study ${ }^{(29)}$ on the secondary interventions group was also focused on the mental health status of the elder person. This was a randomized controlled pilot study that provided an adapted version of problem-solving therapy associated with anxiety control techniques for elder victims of violence who sought help in a community-based treatment. Problem-solving theory is an intervention developed within cognitive-behavioral therapy. It is aimed at teaching individuals a set of cognitive and behavioral skills (tools) to improve their ability to cope more effectively with a variety of stressors that potentially lead to negative physical health and mental health outcomes ${ }^{(51)}$.

Problem-solving therapy is effective in reducing depressive symptoms and controlling anxiety, and quite effective in addressing frequent problems of old age related to disability, decreased mobility, activities of daily living, and social functioning ${ }^{(3)}$.

The three main factors addressed in the interventions described above were impotence, assertiveness, and (indirectly) problem-solving skills, which are individual traits rooted in cultural and social factors ${ }^{(49)}$. Society often infantilizes elder people ${ }^{(52)}$ and associates old age with disability and illness ${ }^{(53)}$, making elder people question themselves and their value, as well as their ability to find a place in society ${ }^{(37)}$.

The study ${ }^{(28)}$ describing the implementation of an intervention to manage cases of violence or risk of violence in an American Indian reservation based on a model used by Maori natives in New Zealand with principles of restorative justice was the most discordant article among the seven selected. This study markedly differs from the others because it adopted a community approach. Despite its focus on the elder person, the difficulty of this intervention involved the particularity of the scenario. Some of the challenges were the different conceptualizations of 
what consists elder abuse for the indigenous culture and the secular culture ${ }^{(39)}$, along with the social role of the elder person in the indigenous culture that influenced the success of this intervention.

All studies in this systematic review had positive outcomes and could be implemented in nursing practice, particularly those of the primary intervention group, which were based on deconstructing false beliefs about what ageing means, and building assertiveness and empowerment, which are all already attempted by nurses, especially those working in public health services. The nursing professional is in a privileged position to prevent elder abuse, because they work with elder people and the whole population at the primary intervention level and across all levels of nursing care.

According to the quality assessment performed in the study using the MMAT, the seven selected studies did not describe the study design in detail, used small sample sizes, did not provide enough information to understand the randomization of participants and the blindness of the study, and did not favor the replication of studies in other contexts. This finding corroborates that reported by other authors ${ }^{(36,54)}$ and represents the current scenario of the literature on interventions aimed at preventing elder abuse. This lack of methodological rigor of studies in this area directly affects managers who need scientific-based evidence for the development of public policies and decisions concerning this population ${ }^{(11)}$.

The main limitations identified in the selected studies were the small sample sizes, and the greatest sample size was of 69 participants ${ }^{(29)}$. Another one was the absence of a detailed description of the intervention applied, such as the time of each meeting and the technologies used, both of which are details that allow the replication of the intervention. Another limitation was the lack of an evaluation of results after the application of the intervention, through which would be possible to measure its effectiveness. The context of some interventions also appeared as a limitation, since it presented particularities and characteristics that influenced the positive response, and would be modified in cases of elder abuse victims of violence in different circumstances. All studies selected for the review had their full text available through the university database system, but only a small number of them were free for the whole community.

A limitation of this systematic review was the selection only of studies targeting the elder person. This restricted the findings and consequently, the applicability to the different components of elder abuse: relationship, perpetrator and environment; and the definition of elder people as individuals of 60 years of age or more, which excluded studies from countries with different definitions; and the language limitation.

\section{CONCLUSION}

The interventions to prevent elder abuse that target the elder person can be divided into two groups: primary level interventions, and secondary level interventions. Health education through elder people coexistence groups and mental health care were the prevalent approach to elder abuse prevention in the primary and secondary intervention group, respectively. All interventions had positives outcomes and could be implemented within the nursing care practice. There is still a shortage of studies on abuse prevention in the field.

\section{RESUMO}

Objetivo: Identificar na literatura as intervenções propostas para prevenir maus-tratos a idosos residentes na comunidade. Método: Revisão sistemática mista conduzida de acordo com a recomendação PRISMA (Preferred Reporting Items for Systematic Review and Meta-analysis). O protocolo desta revisão sistemática foi registrado no International Prospective Register of Systematic Reviezws. Foram incluídos estudos publicados entre janeiro de 2004 e dezembro de 2019 nas bases de dados: LILACS, IBECS, CUMED, CINAHL, MEDLINE e SciELO. Para avaliar a qualidade metodológica de cada estudo incluído, foi utilizada a Ferramenta para Análise de Métodos Mistos. Resultados: Sete estudos formaram a amostra final. Após as análises, emergiram dois grupos, o grupo de intervenção de nível primário, onde foi utilizada educação em saúde e grupos de abuso de idosos coexistentes; e o grupo de intervenção de nível secundário, focado principalmente na atenção à saúde mental dos idosos vítimas de abuso. Conclusão: Estudos de intervenção para prevenir o abuso de idosos ainda são escassos. Todos os estudos selecionados tiveram resultado positivo, e todas as intervenções podem ser implementadas na prática assistencial de enfermagem.

\section{DESCRITORES}

Maus-Tratos ao Idoso; Violência; Enfermagem Geriátrica; Revisão Sistemática.

\section{RESUMEN}

Objetivo: Identificar las intervenciones propuestas en la literatura dirigidas a prevenir el maltrato a personas mayores residentes en la comunidad. Método: Revisión sistemática de métodos mixtos realizada de acuerdo con la recomendación PRISMA (Preferred Reporting Items for Systematic Review and Meta-analysis). El protocolo para esta revisión sistemática se registró en el International Prospective Register of Systematic Reviews. Se incluyeron los estudios publicados entre enero de 2004 y diciembre de 2019 en las bases de datos: LILACS, IBECS, CUMED, CINAHL, MEDLINE y SciELO. Para evaluar la calidad metodológica de cada estudio incluido, se utilizó la Herramienta de Análisis de Métodos Mixtos. Resultados: Siete estudios formaron la muestra final. Después del análisis, surgieron dos grupos, el grupo de intervención de nivel primario, donde se utilizó educación para la salud y grupos de abuso de las personas mayores coexistentes; y el grupo de intervención de nivel secundario, enfocado principalmente en la atención de salud mental de personas mayores víctimas de abuso. Conclusión: Los estudios de intervención para prevenir el maltrato a las personas mayores aún son escasos. Todos los estudios seleccionados tuvieron resultados positivos y todas las intervenciones se pueden implementar en la práctica del cuidado de enfermería. 


\section{DESCRIPTORES}

Maltrato al Anciano; Violencia; Enfermería Geriátrica; Revisión Sistemática.

\section{REFERENCES}

1. World Health Organization. Missing voices: views of older persons on elder abuse [Internet]. Geneva: WHO; 2002 [cited 2019 Oct 17]. Available from: https://apps.who.int/iris/handle/10665/67371

2. Brasil. Ministério da Saúde. Estatuto do Idoso [Internet]. Brasília; 2003 [citado 2019 out. 17]. Disponível em: http://bvsms.saude.gov.br/ bvs/publicacoes/estatuto_idoso_3edicao.pdf.

3. Pillemer K, Burnes D, Riffin C, Lachs MS. Elder abuse: global situation, risk factors, and prevention strategies. Gerontologist. 2016;56 Suppl 2:S194-205. doi: https://dx.doi.org/10.1093/geront/gnw004

4. Corbi G, Grattagliano I, Ivshina E, Ferrara N, Solimeno Cipriano A, Campobasso C, et al. Elderly abuse: risk factors and nursing role. Intern Emerg Med. 2015;10(3):297-303. doi: https://dx.doi.org/10.1007/s11739-014-1126-z

5. Simone L, Wettstein A, Senn O, Rosemann T, Hasler S. Types of abuse and risk factors associated with elder abuse. Swiss Med Wkly. 2016;146:w14273. doi: https://dx.doi.org/smw.2016.14273

6. Dong X, Simon MA. Elder abuse as a risk factor for hospitalization in older persons. JAMA Intern Med. 2013;173(10):911-7. doi: http:// dx.doi.org/10.1001/jamainternmed.2013.238

7. Dong X, Chen R, Wu B, Zhang NJ, Mui ACY-S, Chi I. Association between elder mistreatment and suicidal ideation among CommunityDwelling Chinese older adults in the USA. Gerontology. 2015;62(1):71-80. doi: https://dx.doi.org/ 10.1159/000437420

8. Roepke-Buehler SK, Simon M, Dong X. Association between depressive symptoms, multiple dimensions of depression, and elder abuse. J Aging Health. 2015;27(6):1003-25. doi: http://dx.doi.org/10.1177/0898264315571106

9. Rusac S. Elderly abuse and alcohol consumption. Coll Antropol. 2015;39(4):869-75. PMID: 26987154

10. Burnes D, Lachs MS. The case for individualized goal attainment scaling Measurement in elder abuse interventions. J Appl Gerontol. 2017;36(1):116-22. doi: http://dx.doi.org/10.1177/0733464815581486

11. Day A, Boni N, Evert H, Knight T. An assessment of interventions that target risk factors for elder abuse. Health Soc Care Community. 2017;25(5):1532-41. doi: http://dx.doi.org/10.1111/hsc.12332

12. Cattaneo LB, Goodman LA. What is empowerment anyway? A model for domestic violence practice, research, and evaluation. Psychol Violence. 2015;5(1):84-94. doi: http://dx.doi.org/10.1037/a0035137

13. Mosqueda L. Develop Prevention. Why am I hopeful? [Internet].Los Angeles: USC Center on Elder Mistreatment; 2015 [cited 2019 Oct 21]. Available from: https://eldermistreatment.usc.edu/develop-prevention/

14. Moore C, Browne C. Emerging innovations, best practices, and evidence-based practices in elder abuse and neglect: a review of recent developments in the field. J Fam Violence. 2017;32(4):383-97. doi: https://dx.doi.org/10.1007/s10896-016-9812-4

15. Hirst SP, Penney T, McNeill S, Boscart VM, Podnieks E, Sinha SK. Best-practice guideline on the prevention of abuse and neglect of older adults. Can J Aging. 2016;35(2):242-60. doi: https://dx.doi.org/10.1017/S0714980816000209

16. Fearing G, Sheppard CL, McDonald L, Beaulieu M, Hitzig SL. A systematic review on community-based interventions for elder abuse and neglect. J Elder Abuse Negl. 2017;29(2-3):102-33. doi: https://dx.doi.org/10.1080/08946566.2017.1308286

17. Ayalon L, Lev S, Green O, Nevo U. A systematic review and meta-analysis of interventions designed to prevent or stop elder maltreatment. Age Ageing. 2016;45(2):216-27. doi: https://dx.doi.org/10.1093/ageing/afv193

18. Baker PR, Francis DP, Hairi NN, Othman S, Choo WY. Interventions for preventing abuse in the elderly. Cochrane Database Syst Rev. 2016;(8):CD010321. doi: https://dx.doi.org/10.1002/14651858.CD010321.pub2

19. Ploeg J, Fear J, Hutchison B, MacMillan H, Bolan G. A systematic review of interventions for elder abuse. J Elder Abuse Negl. 2009;21(3):187210. doi: $10.1080 / 08946560902997181$

20. Shamseer L, Moher D, Clarke M, Ghersi D, Liberati A, Petticrew M, et al. Preferred reporting items for systematic review and meta-analysis protocols (PRISMA-P) 2015: elaboration and explanation. BMJ. 2015;349:g7647. doi: http://dx.doi.org/10.1136/bmj.g7647

21. Pluye P, Hong QN. Combining the power of stories and the power of numbers: mixed methods research and mixed studies reviews. Annu Rev Public Health. 2014;35(1):29-45. doi: http://dx.doi.org/10.1146/annurev-publhealth-032013-182440

22. Armstrong R, Waters E, Doyle J. Reviews in public health and health promotion. In: Higgins JP, Green S, editors. Cochrane handbook for systematic reviews of interventions. London: John Wiley \& Sons; 2008. p. 593-606.

23. United Nations. Report of the second world assembly on ageing. Madrid; 2002.

24. Schardt C, Adams MB, Owens T, Keitz S, Fontelo P. Utilization of the PICO framework to improve searching PubMed for clinical questions. BMC Med Inform Decis Mak. 2007;7(1):16. doi: https://dx.doi.org/ 10.1186/1472-6947-7-16

25. Hong QN, Pluye P, Bujold M, Wassef M. Convergent and sequential synthesis designs: implications for conducting and reporting systematic reviews of qualitative and quantitative evidence. Syst Rev [Internet]. 2017 [cited 2019 Oct 17];6:61. Available from: https:// systematicreviewsjournal.biomedcentral.com/articles/10.1186/s13643-017-0454-2

26. Pluye $\mathrm{P}$, Robert E, Cargo M, Bartlett G, $\mathrm{O}^{\prime}$ Cathain A, Griffiths F, et al. Appraising qualitative, quantitative and mixed methods studies included in mixed studies reviews: The MMAT [Internet]. Hamilton: McMaster University; 2011 [cited 2019 Oct 17]. Available from: https://www.nccmt.ca/knowledge-repositories/search/232 
27. Sandelowski M, Leeman J, Knafl K, Crandell JL. Text-in-context: a method for extracting findings in mixed-methods mixed research synthesis studies. J Adv Nurs. 2013;69(6):1428-37. doi: http://dx.doi.org/10.1111/jan.12000

28. Holkup PA, Salois EM, Tripp-Reimer T, Weinert C. Drawing on wisdom from the past: an elder abuse intervention with tribal communities. Gerontologist. 2007;47(2):248-54. doi: https://dx.doi.org/ 10.1093/geront/47.2.248

29. Sirey JA, Berman J, Salamone A, DePasquale A, Halkett A, Raeifar E, et al. Feasibility of integrating mental health screening and services into routine elder abuse practice to improve client outcomes. J Elder Abuse Negl. 2015;27(3):254-69. doi: http://dx.doi.org/10.1080/08 946566.2015 .1008086

30. Tetterton S, Farnsworth E. Older women and intimate partner violence: effective interventions. J Interpers Violence. 2011;26(14):2929-42. doi: http://dx.doi.org/10.1177/0886260510390962

31. Despaigne Vinent M, Jimenez Betancourt E, Martinez Despaigne B. Intervención educativa sobre violencia a integrantes de la Universidad del Adulto Mayor "24 de Febrero". Medisan [Internet]. 2011 [citado 2019 Oct. 17];15(1):105-11. Disponible en: http://scielo.sld.cu/scielo. php?script=sci_arttext\&pid=S1029-30192011000100015\&lng=es\&nrm=iso\&tlng=es

32. Díaz Hernández S, Camejo Pérez YM, Camejo Pérez YM. Programa de intervención educativa para promover conductas asertivas en el adulto mayor. Mediciego [Internet]. 2012 [citado 2019 Oct. 12];18(2). Disponible en: http://www.revmediciego.sld.cu/index.php/ mediciego/article/view/325

33. Díaz Hernández Y, Mármol Sóñora L, Oscaña Leal Al, Maldonado Álvarez C, Angulo Ledón YA, Mármol Ocaña L. Diseño de una intervención educativa para prevenir y controlar la violencia contra adultos mayores de una población de Ciego de Ávila. Mediciego [Internet]. 2014 [citado 2019 Oct. 12];20(2). Disponible en: http://www.revmediciego.sld.cu/index.php/mediciego/article/view/156/1483

34. Estebsari F, Dastoorpoor M, Mostafaei D, Khanjani N, RahimiKhalifehkandi Z, Rahimi Foroushani A, et al. Design and implementation of an empowerment model to prevent elder abuse: a randomized controlled trial. Clin Interv Aging. 2018;13:669-79. doi: https://dx.doi. org/10.2147/CIA.S158097

35. Blair A, Ross NA, Gariepy G, Schmitz N. How do neighborhoods affect depression outcomes? A realist review and a call for the examination of causal pathways. Soc Psychiatry Psychiatr Epidemiol. 2014;49(6):873-87. doi: http://dx.doi.org/10.1007/s00127-013-0810-z

36. Greenberg LS. Emotion-focused therapy of depression. Pers Exp Psychother. 2017;16(2):106-17. doi: https://dx.doi.org/10.1080/147797 57.2017.1330702

37. Teresi JA, Burnes D, Skowron EA, Dutton MA, Mosqueda L, Lachs MS, et al. State of the science on prevention of elder abuse and lessons learned from child abuse and domestic violence prevention: toward a conceptual framework for research. J Elder Abuse Negl. 2016;28(45):263300. doi: https://dx.doi.org/10.1080/08946566.2016.1240053

38. Naughton C, Drennan J, Lyons I, Lafferty A. The relationship between older people's awareness of the term elder abuse and actual experiences of elder abuse. Int Psychogeriatrics. 2013;25(8):1257-66. doi: https://dx.doi.org/10.1017/S1041610213000513

39. Jervis LL, Sconzert-Hall W, The Shielding American Indian Elders Project Team. The conceptualization of mistreatment by older American Indians. J Elder Abuse Negl. 2017;29(1):43-58. doi: https://dx.doi.org/10.1080/08946566.2016.1249816

40. Goodman LA, Cattaneo LB, Thomas K, Woulfe J, Chong SK, Smyth KF. Advancing domestic violence program evaluation: development and validation of the Measure of Victim Empowerment Related to Safety (MOVERS). Psychol Violence. 2015;5(4):355-66. doi: http:// dx.doi.org/10.1037/a0038318

41. Kirkham JG, Choi N, Seitz DP. Meta-analysis of problem solving therapy for the treatment of major depressive disorder in older adults. Int J Geriatr Psychiatry. 2016;31(5):526-35. doi: http://dx.doi.org/10.1002/gps.4358

42. Warland J, McKellar L, Diaz M. Assertiveness training for undergraduate midwifery students. Nurse Educ Pract. 2014;14(6):752-6. doi: https://dx.doi.org/10.1016/j.nepr.2014.09.006

43. Green J. Enhancing assertiveness in district nurse specialist practice. Br J Community Nurs. 2016;21(8):400-3. doi: http://dx.doi. org/10.12968/bjcn.2016.21.8.400

44. Speed BC, Goldstein BL, Goldfried MR. Assertiveness training: a forgotten evidence-based treatment. Clin Psychol Sci Pract. 2018;25(1):e12216. doi: http://dx.doi.org/10.1111/cpsp.12216

45. Khademi Mofrad SH, Mehrabi T. The role of self-efficacy and assertiveness in aggression among high-school students in Isfahan. J Med Life [Internet]. 2015 [cited 2019 Oct 17];8(spe 4):225-31. Available from: https://www.ncbi.nlm.nih.gov/pmc/articles/PMC5319278/

46. Avşar F, Ayaz Alkaya S. The effectiveness of assertiveness training for school-aged children on bullying and assertiveness level. J Pediatr Nurs. 2017;36:186-90. doi: https://dx.doi.org/10.1016/j.pedn.2017.06.020

47. Boket EG, Bahrami M, Kolyaie L, Hosseini SA. The effect of assertiveness skills training on reduction of verbal victimization of high school students. Int J Humanit Cult Stud [Internet]. 2016 [cited 2019 Oct 21];(Aug). Available from: https://www.ijhcs.com/index.php/ijhcs/article/ view/2857/2693

48. Asi Karakaş S, Okanli AE. The effect of assertiveness training on the mobbing that nurses experience. Workplace Health Saf. 2015;63(10):44651. doi: http://dx.doi.org/10.1177/2165079915591708

49. Martha-Rose Cl. Multimodal counselling therapy in the management of intimate partner violence among married couples in Owerri, Nigeria. Asian J Soc Sci Manag Stud. 2016;3(3):229-33. doi: https://dx.doi.org/10.20448/journal.500/2016.3.3/500.3.229.233

50. Nezu CM, Nezu AM, Colosimo MM. Case formulation and the therapeutic alliance in contemporary Problem-Solving Therapy (PST). J Clin Psychol. 2015;71(5):428-38. doi: http://dx.doi.org/10.1002/jclp.22179

51. Pickering CEZ, Phillips LR. Development of a causal model for elder mistreatment. Public Health Nurs. 2014;31(4):363-72. doi: http:// dx.doi.org/10.1111/phn.12108 
52. Torres TL, Camargo BV, Boulsfield AB, Silva AO. Social representations and normative beliefs of aging. Ciênc Saúde Coletiva. 2015;20(12):3621-30. doi: http://dx.doi.org/ 10.1590/1413-812320152012.01042015

53. Mysyuk Y, Westendorp RGJ, Lindenberg J. How older persons explain why they became victims of abuse. Age Ageing. 2016;45(5):695702. doi: https://dx.doi.org/10.1093/ageing/afw100

54. McDonald L, Hitzig SL, Pillemer KA, Lachs MS, Beaulieu M, Brownell P, et al. Developing a research agenda on resident-to-resident aggression: recommendations from a consensus conference. J Elder Abuse Negl. 2015;27(2):146-67. doi: http://dx.doi.org/10.1080/089 46566.2014.995869 